\title{
WILDLIFE MANAGEMENT IN THE YUKON TERRITORY ${ }^{1}$ BY FRED FRASER ${ }^{2}$
}

\section{F. FRASER}

Fred Fraser was bom in Revelstroke, British Columbia in 1895. After the first world war and service with the R.C.A.F. during 1941-44, be joined the Department of Resources and Development in 1944 and went to Yellowknife, Nortbwest Territories, as stipendiary magistrate, mining recorder and local administrator. In 1948 be was promoted to District Administrator of the Mackenzie District. In 1949 be was transferred to Ottawa and assumed the position of Assistant Chief of the Lands Division of the Department. In 1950-51 be was appointed Commissioner of the Yukon Territory, and is now chief of the Northern Administration Division of the Department of Resources and Development. His pioneer parents were settlers of Revelstoke, having come with the construction of the C.P.R. from Winnipeg. His mother resides in Vancouver at the age of 97.

\section{ABSTRACT}

In the early years of the development of the Yukon the game resources were largely wasted because of lack of management, the population depending to a great extent upon moose and caribou for its meat. Altbough conditions improved greatly in the interim between 1910 and 1949, the greatest indication of improvement bas come about since the formation of a game department as a branch of the Territorial Government in 1949. Registered trap lines were introduced in 1950 to regulate the trapping of all fur bearing animals.

The majority of the trappers are native Indians of the Yukon and their predilection for numerous dogs bas been a severe strain on the cariboo and moose, the Yukon producing few fish as a substitute. As a result of education in conservation, bowever, the situation is improving.

In 1951 trial implantations of elk and bison were made in the soutbern portion of the Territory, the elk from one of the National Parks in Alberta and the bison from Alaska. If these experiments prove successful, additional animals will be imported. The danger of implanting an exotic species is realized and the wildlife antborities are watching developments with interest.

The Yukon is internationally known for its big game bunting, the climate and food varieties producing splendid animals of all native species. With proper management of the game resources of the Yukon, with a continued programme of education, and finally, with the co-operation of the people who live and work in the Territory, the Yukon should long continue to be what it is today, an attraction to the tourist, a cynosure to the tropby bunter of Canada and the United States and a thoronghly pleasant place to live in the year round.

Prior to 1895 the area now known as the Yukon Territory formed part of the unorganized Northwest Territories. In 1895 it was created a district of the Northwest Territories, and in 1898 the Yukon Territory was created 
in the caribou herds which frequent the area between the Alaska boundary and the Northwest Territories boundary, along and north of the 65th Parallel. The legal sale of game meat was first prohibited in 1947. The policy of allowing natives to augment their livelihood by the sale of game meat was continued however, and it has been found necessary to add new restrictions to prevent abuse.

The staff of the Game Branch at the present time consists of a Superintendent and one assistant; all officers of the Royal Canadian Mounted Police are game officers and administer and enforce the game and trapping regulations in detachment areas. In addition, licenced guides are honorary game officers and have shown their ability and willingness to assist in stricter enforcement of the regulations.

Registered trapline legislation has been introduced. It has not been found feasible, however, to extend this legislation to those areas which lie north of the 65th Parallel of north latitude, the trappers in this area being nomadic bands of Indians. South of the 65th Parallel, however, all traplines are now registered. Because of the nomadic life of the natives of the Yukon Territory, a good deal of leniency must be shown in the enforcement of game and trapping regulations insofar as they affect these people. A program of education in conjunction with the officials of the Indian Affairs Branch is being conducted and is showing results. They are learning the meaning of game conservation and particularly the effect that the wastage of wildlife has upon their economy. The native has long counted the number of his $\operatorname{dogs}$ as a measure of his wealth and of his standing in his own community. This predilection places a heavy load on caribou and moose. The Yukon is deficient in fish-bearing lakes, and the native depends upon fresh meat for his beasts of burden. Here again it will only be by education that this situation can be corrected. Every endeavour is being made to teach the native that fish should be used as dog food where it is available. The Indian Affairs Branch provides free nets.

The organization of the registered trapline system commenced in the Spring of 1950, following the trapping season, and the registration of traplines was completed and ready for the season of 1951. Approximately four hundred traplines are registered. The great majority of these belong to Indians. Nearly all of the suitable trapping areas in the southern portion of the Territory are held by natives. The initial registration fee for a trapline is $\$ 10.00$, and the renewal fee annually is $\$ 5.00$. Among the fur-bearing animals a quota is placed only on beaver, fifteen being the number allowed to be trapped. Up to the present time, however, experience has shown that where a trapper, particularly a native, has an excess number of beaver in his area, he will take far in excess of his quota and will apportion the pelts among the less fortunate trappers who have been unable to fill their quota. It is planned, therefore, to change the regulations to permit a trapper to take one beaver for each live lodge on his area. The operation of this scheme will be closely watched for two or three years. It is felt, however, that with adequate supervision it should be a success. The main objections seem to be that those 
trappers fortunate enough to have within their registered area suitable land for the propagation of beaver, will be able to take a large number of animals. Those trappers who occupy more mountainous country will not gain any advantage from such a change in the regulations and will undoubtedly be envious of their more fortunate neighbors. There is no doubt that this will give rise to some poaching and to disagreement among individual trappers. The natives are almost entirely concerned in this.

Hitherto the shooting of beaver has been permitted during the open season, which includes the late weeks of spring when the ice has disappeared. The result of this permission to shoot beaver has been the almost entire cessation of trapping by the native population, who wait until the ice is gone to take their quota of animals. They are not particular in the shooting and many of the pelts are ruined or will bring a low price at the Trading Post because of damage from bullet wounds in the back. Again, the native does not select the animal he shoots but will kill any animal though he knows he is using up his quota and getting a less valuable pelt. Another result of this practice is that the native will continue taking beaver by shooting until he has acquired fifteen large pelts, in the doing of which he may kill twenty-five or thirty beaver. If he finds that he is unable to dispose of these pelts legally, he will destroy them or hold them over until the next year.

With the decline in price for fox and lynx, the native must depend largely upon beaver for his livelihood, the rat population of the Yukon being sparse. It is, therefore, essential that everything be done to educate the native in the proper use of his resources and to conserve and re-establish the beaver population.

Total Number of Specified Fur Taken by Seasons

Bear, White

Bear, Not Specified

Beaver

Fisher

Fox, Red

Fox, White

Fox, Cross

Fox, Silver

Fox, Black

Fox, Blue

Lynx

Martin

Mink

Muskrat

Otter

Weasel

Wolverine

Squirrel
1948-49

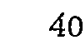

1,102

27

212

2

133

27

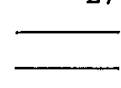

552

1,163

883

27,681

30

749

198

119,151
1949-50

2
49

2,727

9

115

3
67

14

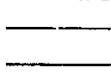

631

1,439

692

54,634

64

1,382

157

91,542
$1950-51$ 
Two experiments were carried out in the year 1951, the transplantation of elk and bison. Twenty head of elk, consisting of fifteen cows and five bulls, were obtained through the good offices of the Department of Resources and Development, National Parks Branch, from the National Park at Elk Island in the Province of Alberta. These animals were transported in two trucks and were liberated near Braeburn Lake, north of Whitehorse. The animals were in good condition when received. It is too early, however, to say whether they will become acclimatized and whether they will adapt themselves to their new environment. No further additions will be made to the elk population by importation until it is known that the imported herd is increasing in numbers. On the 21 st of September six head of bison, consisting of four cows and two bulls were received by way of a donation from the Alaska Wildlife Service. These animals were also liberated in the Braeburn Lake area. Here again a close watch will be maintained to see how the herd is progressing and no further importations will be made until the progress and welfare of the present small herd is assured.

As has been said before, the woodland caribou is increasing in number, and with proper protection, should continue to do so. Little is known of the barrenland caribou which frequent the tundra region north of the 65th Parallel. These animals tend to migrate towards the Northwest Territories and the delta of the Mackenzie River during the winter season. The herd appears to be increasing in numbers and an investigation will be carried out by a qualified mammalogist within the next year or two to get some reliable data. The third member of the deer family in the Yukon, the moose, appears to be increasing in numbers in certain areas not readily accessible from the Alaska Highway. However, there is a heavy strain placed on the moose population. The number of game licenses increases each year, and the demand for wild game meat has encouraged the natives to take moose in the open season, irrespective of the sex of the animal, which meat is sold to hospitals, mission schools and individual buyers. A vigorous campaign to prevent this wastage will be undertaken in the coming hunting season.

Trophy hunting is an important item in the economy of the Territory. Approximately one hundred non-resident big game licences were sold in 1951. The license fee has been increased from $\$ 100.00$ to $\$ 150.00$, and the licence permits the holder to take one animal of each species. No trophy tax is levied, and an export permit is granted without charge. Nonresident hunters must be accompanied by a guide. The system used in the Province of British Columbia has now been adopted in the Yukon Territory, whereby guides are licenced as Class " $\mathrm{A}$ ", " $\mathrm{B}$ ", or " $\mathrm{C}$ ". Commencing in 1952, licenced guides will register the area within which they are operating. Certain areas will remain open to permit all guides to hunt therein to prevent monopoly of certain species, particularly of the sheep family. It is estimated that non-resident hunters spend annually in the Yukon Territory a sum in excess of two hundred thousand dollars. 
In addition to the non-resident licences, a special license for bear hunting only is issued in the spring for the season May 1st to June 30th. The fee is $\$ 50.00$. Licensed guides are being encouraged to open up new areas in order to remove some of the strain from areas now readily accessible.

Grouse of three species and ptarmigan are common and in large numbers in the Yukon. Non-resident bird licence fees are $\$ 10.00$, which entitles the holder to take a total of fifteen birds in any one day and thirty in the aggregate in the season. Waterfowl, though not large in numbers, are occasionally hunted and the bag limit is as follows: ducks 7; geese 5: rails and coots 25, in one day. In any one season-ducks 100; geese 25 .

Because of the climate and feed conditions, Yukon big game animals rank among the most desirable on the North American Continent from the trophy hunter's viewpoint. In 1950 a moose head was taken with a spread of seventy-six inches, the second largest known trophy. Heads with a spread of over seventy inches are not uncommon. The woodland caribou in the Yukon Territory is the last large herd in Canada and offers magnificent trophies. Yukon Territory harbors one of the North America's most prized trophies, the White Dall sheep, of which several record heads with curls of over forty-seven inches have been taken. In certain mountain areas this specie is relatively plentiful and is keenly sought by trophy hunters. Stone sheep are also found within our borders, chielly in the southern part of the Territory, and is considered a worthy trophy for those lucky enough to obtain it. The grizzly bear is also plentiful and although not as large as the Alaska Brown bear, offers the trophy hunter excellent sport.

The most widely known big game districts are:

(1) A large area extending northward from Kluane Lake, to the upper White River, including the Donjek River basin (made famous in Senator Young's book "Trophies Won and Lost"), part of which now lies within the Kluane Game Sanctuary;

(2) Kusawa Lake area (Arkell) and the region adjacent to Carcross and Teslin Lakes in southern Yukon;

(3) Areas in the vicinity of the Big Salmon, McMillan, Ross, Stewart and Pelly Rivers.

Further north, game is found in the areas bounded by the Yukon, Porcupine, Peel, Wind and Bonnet Plume Rivers, the last two mentioned rivers have been vividly described in Jim Bond's books, "From Out of the Yukon", and "North America's Number One Trophy". The topography of the Yukon is outstanding in its variety and beauty and camera hunting is growing as a corollary to trophy hunting. The foliage colors in the fall particularly offer variety for color photography, equal to any other part of the North American Continent. 
The following statistics show big game taken by non-resident hunters and licences sold:

\begin{tabular}{|c|c|c|c|}
\hline & $1948-49$ & $1949-50$ & $1950-51$ \\
\hline Sheep & - & 59 & 72 \\
\hline 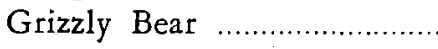 & 一 & 62 & 57 \\
\hline Caribou & - & 23 & 40 \\
\hline Moose & - & 38 & 38 \\
\hline 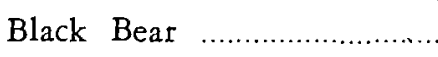 & - & 12 & 6 \\
\hline Goat & - - & 20 & 8 \\
\hline 'Wolf & . - & 5 & 7 \\
\hline Wolverine & . - - & 3 & - \\
\hline $\begin{array}{l}\text { Non-Resident Bird } \\
\text { Licences sold................. }\end{array}$ & 4 & 7 & 36 \\
\hline $\begin{array}{l}\text { Non-Resident Big Game } \\
\text { Licences Sold }\end{array}$ & 67 & 75 & 92 \\
\hline
\end{tabular}

Hunting Licences, Resident, issued season 1951, total 1317.

Guides' Licences issued season 1951:

$\begin{array}{ll}\text { Grade "A" Guides........... } & 11 \\ \text { Grade "B" Guides. ......... } & 19 \\ \text { Grade "C" Guides........... } & 33\end{array}$

A policy of publicising the opportunities for the tourist and sportsman in the Yukon, together with education in game conservation, should produce within a few years a proper management of game resources and increased tourist attraction.

The question of the control of predators in the Yukon has been, as in all other areas of the North American Continent, one of confusion and controversy. Bounties have been paid for many years on wolves and coyotes and the total payments made since 1898 for this purpose exceed one hundred thousand dollars. No one can say to-day that the number of predators has decreased in that time. The Administration feels, therefore, that monies paid for this purpose are wasted. Legislation to repeal the payment of bounties on predators was passed at the last session of the Yukon Council. If there is any indication of an undue increase in the wolf population, the employment of professional wolf hunters will be considered. It has been found here, as elsewhere, that reports received about the prevalence of wolves are invariably greatly exaggerated. Those to whom bounties have been paid in the past have taken animals as a result of a casual encounter or trapping operations rather than the result of an effort to destroy the wolf for the sake of conservation. In other words, the money paid out in bounties has been paid as a reward to the casual hunter or as a subsidy to trappers. As no bounties are paid in the North- 
west Territories, there is no doubt that many of the pelts being presented for payment in the Yukon have been trapped or shot outside of the Territory.

The following statistics show bounty paid on total number of wolves and coyotes taken.

\begin{tabular}{|c|c|c|c|}
\hline & $1948-49$ & $1949-50$ & $1950-51$ \\
\hline $\begin{array}{l}\text { Number of coyotes taken } \\
\text { (on which } \$ 10 . .00 \\
\text { bounty was paid }\end{array}$ & 485 & 135 & 100 \\
\hline $\begin{array}{l}\text { Number of wolves taken } \\
\text { (On which } \$ 20.00\end{array}$ & 287 & 135 & 111 \\
\hline
\end{tabular}

